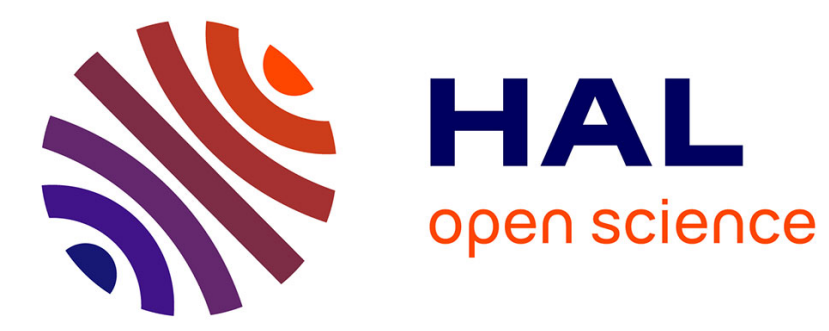

\title{
[Cp*Ru]-catalyzed selective coupling/hydrogenation
}

I. Labed, A. Labed, Yang Sun, F. Jiang, Mathieu Achard, Sylvie Dérien, Z.

Kabouche, Christian Bruneau

\section{To cite this version:}

I. Labed, A. Labed, Yang Sun, F. Jiang, Mathieu Achard, et al.. [Cp*Ru]-catalyzed selective coupling/hydrogenation. Catalysis Science \& Technology, 2015, 5 (3), pp.1650-1657. 10.1039/C4CY01303D . hal-01141121

HAL Id: hal-01141121

https://hal-univ-rennes1.archives-ouvertes.fr/hal-01141121

Submitted on 15 Jun 2015

HAL is a multi-disciplinary open access archive for the deposit and dissemination of scientific research documents, whether they are published or not. The documents may come from teaching and research institutions in France or abroad, or from public or private research centers.
L'archive ouverte pluridisciplinaire HAL, est destinée au dépôt et à la diffusion de documents scientifiques de niveau recherche, publiés ou non, émanant des établissements d'enseignement et de recherche français ou étrangers, des laboratoires publics ou privés. 


\section{[Cp*Ru]-Catalyzed Selective Coupling/Hydrogenation}

I. Labed. ${ }^{b}$ A. Labed. ${ }^{b}$ Y. Sun. ${ }^{a}$ F. Jiang. ${ }^{a}$ M. Achard. ${ }^{a *}$ S. Dérien. ${ }^{a}$ Z. Kabouche. ${ }^{b}$ and C. Bruneau ${ }^{a}$

Accesses to 3,4- and 3,5-disubstituted piperidine derivatives have been achieved through [Cp*Ru]-catalyzed intermolecular coupling of allylic alcohols and propargylic amides. Tandem transformation was also possible via chemoselective [Cp*Ru]-catalyzed hydrogenation of the resulting homo-dienes.

\section{Introduction}

In regards to their applications in agrochemicals and pharmaceuticals, functionalized piperidine derivatives represent an important class of alkaloids and new methodologies for the preparation of substituted piperidine derivatives have attracted the attention of many researchers. ${ }^{1,2}$ Traditional approaches to access polyfunctionalized piperidines usually involve alkylation, arylation of piperidone derivatives, hydrogenation of substituted pyridine or cycloadditions. ${ }^{3-6}$ Multicomponent cascade transformations constitute new straightforward protocols for the syntheses of polysubstituted piperidines. ${ }^{6}$ Recently, direct functionalization of piperidines have emerged as excellent alternatives to the aforementioned methodologies. Among the latter, neutral redox processes involving the formation of transient azomethine ylides from aldehydes and amines have been efficiently used for the preparation of 2- and 2,3-(di)substituted piperidines. ${ }^{2 f, 7}$ The preparation of cyclic enamines or enamides containing reactive carbons at the $\alpha$ and $\beta$ positions towards nucleophile and electrophile, respectively constitute another important approach for the preparation of 2,3-disubstituted piperidines. ${ }^{8}$ On the other hand, the use of transition metal complexes has gained increasing importance due to their ability to construct valuable $\mathrm{N}$-heterocycles. Hydrogen borrowing or hydrogen autotransfer processes have been efficiently applied for the preparation of piperidine derivatives from primary amines and 1,5-pentanediols. ${ }^{2 a, b, e, 9}$ This methodology also allowed the postfunctionalization of cyclic amines at 2- or 3-position through metal-catalyzed redox processes. ${ }^{10}$ Cross Dehydrogenative Coupling (CDC) involving the formation of electrophilic iminium ion via oxidative processes has found broad application in $\alpha$ functionalization of amines. ${ }^{11}$ Metal-catalyzed $\mathrm{C}-\mathrm{H}$ functionalization of cyclic enamide derivatives proved to be a powerful tool to synthesize substituted piperidines. ${ }^{12}$ Direct functionalization of saturated piperidines represents another interesting approach for either $\alpha$ - or $\beta$-substituted piperidines. ${ }^{13}$ Among the polysubstituted piperidines, 4-phenylpiperidine

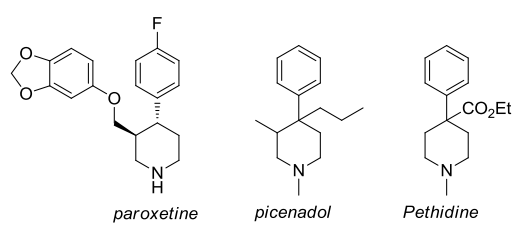

Figure 1 Representative examples of 4-phenylpiperidines 
derivatives such as paroxetine, femoxetine, picenadol, pethidine, terikalant, haloperidol and related structures have found broad applications as antidepressant, antipsychotic and other related biological properties (Figure 1). 4b,14-18 However, straightforward accesses to 4-phenylpiperidine derivatives through transition metal-catalysis remain scarce. ${ }^{19}$

Recently, we reported that [ $\mathrm{Cp} * \mathrm{Ru}$ ]-based catalysts can be judiciously employed in regioselective oxidative coupling between propargylic amines and aliphatic allylic alcohols to offer straightforward accesses to dehydropiperidine derivatives. ${ }^{20}$ Taking advantage of this methodology by substrate scope broadening, we now disclose that $\left\{\left[\mathrm{Ru}\left(\mathrm{Cp}^{*}\right)\left(\mathrm{CH}_{3} \mathrm{CN}\right)_{3}\right] \mathrm{PF}_{6}\right\}$-catalyzed the chemoselective semi-hydrogenation of the resulting homodienes allowing the development of the tandem transformation.

\section{Results and discussion}

Various cyclic enamides $\mathbf{3} \mathbf{f}-\mathbf{3} \mathbf{j}$ were previously prepared from the corresponding linear aliphatic allylic alcohols with propargylic amides $\mathbf{2}$ through ruthenium-catalyzed coupling. ${ }^{20}$ However, during the coupling between cinnamyl alcohol $\mathbf{1 a}$ and propargylic sulphonamide $\mathbf{2} \mathbf{a}$ in the presence of catalytic amount of $\left\{\left[\mathrm{Ru}\left(\mathrm{Cp}^{*}\right)\left(\mathrm{CH}_{3} \mathrm{CN}\right)_{3}\right] \mathrm{PF}_{6}\right\}$, results demonstrate the crucial importance of the substituents on the allylic alcohol on the reaction efficiency and side isomerization (Scheme 1).

Table 1 . Synthesis of 3-methylidene-4-phenyl disubstituted enamide $\mathbf{3 a}{ }^{a}$

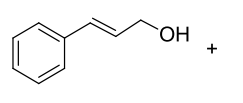

$1 \mathrm{a}$

Entry

1

2

3

4

5

6

7

8

9

$10^{c}$

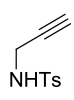

2a

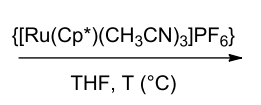

Ratio 1/2

$5 / 1$

$2.5 / 1$

$2 / 1$

$1.5 / 1$

$1 / 1$

$1 / 2$

$1.2 / 1$

$1.2 / 1$

1.2/1

$1.2 / 1$
$\mathrm{T}\left({ }^{\circ} \mathrm{C}\right)$

80

80

80

80

80

80

60

100

125

100
Conversion $^{b}$

35

39

41

48

54

42

0

72

58

95(74)

${ }^{a}$ All reactions were carried out in THF for $15 \mathrm{~h}$ under an inert atmosphere of argon with $\mathbf{2 a} /[\mathrm{Ru}]$ in $1 / 0.05$ molar ratio. ${ }^{b}$ Conversion determined by GC. Number in parentheses is isolated yield after purification. ${ }^{c}$ reactions were carried out in THF for $15 \mathrm{~h}$ under an inert atmosphere of argon with $2 \mathrm{a} /[\mathrm{Ru}]$ in 1/0.08 molar ratio.

Our previously reported procedure involving slow addition of the protected propargylic amine $\mathbf{2} \mathbf{a}$ and $\mathbf{2} \mathbf{b}$ was found to be unsuitable highlighting faster isomerization of $\mathbf{1 a}$ to 3-phenylpropanal than the expected coupling (3fj, Scheme 1). ${ }^{20}$ Therefore, after an initial screening of solvents, THF and DCE were found to be suitable for the 
transformation. The temperature exerted a strong influence on conversion and the formation of 3a was not observed with reaction temperature below $60^{\circ} \mathrm{C}$ (entry 7). Increasing the amount of alcohol 1a highlighted the side formation of undesired hemiaminal ethers presumably resulting from the nucleophilic attack of the alcohol on the cyclic enamide and side formation of aldehyde arising from the isomerisation of the allylic alcohol 1a (entries 1 to 4). A best 1.2:1 ratio of the alcohol limited these side reactions. Performing the reaction in sealed tube at $100{ }^{\circ} \mathrm{C}$ afforded up to $72 \%$ conversion (entry 8 ). It is noteworthy that at higher reaction temperatures above $120^{\circ} \mathrm{C}$, noticeable amount of $p$-toluene sulphonamide resulting from the depropargylation of $2 \mathrm{a}$ was detected (entry 9). Finally, with the best reaction conditions, the use of higher catalyst loading improved the transformation affording almost complete conversion and the formation of $\mathbf{3 a}$ in $74 \%$ isolated yield after a rapid purification by short column chromatography over neutralized silica gel to minimize degradation (entry 10). The importance of the nitrogen protecting group was next investigated with allylic alcohol 1a. Under our optimized reaction conditions, no reaction took place in the presence of propargylic aniline $\mathbf{2} \mathbf{d}$ presumably due to the stronger coordination of the nitrogen atom to the ruthenium center. To our delight, amide $\mathbf{2 c}$, sulphonamide $\mathbf{2 a}$ and carbamate $\mathbf{2} \mathbf{b}$ functionalities were found to be suitable leading to the formation of cyclic products $\mathbf{3 a - c}$ in 70 $87 \%$ range yields (Scheme 1). Similarly, 4-nitrocinnamyl alcohol 1b reacts cleanly with 2a affording $\mathbf{3 d}$ in $65 \%$ isolated yield. In contrast, under similar reaction conditions, 2-substituted allylic alcohols such as methallyl alcohol 1c was found to be less reactive and required a modified procedure involving large excess of the methallyl alcohol $1 \mathbf{c}$ (5 equiv.) to observe the formation of the cyclic enamide product $3 \mathbf{e}$. In these cases, the lower reactivity of the resulting cyclic enamide

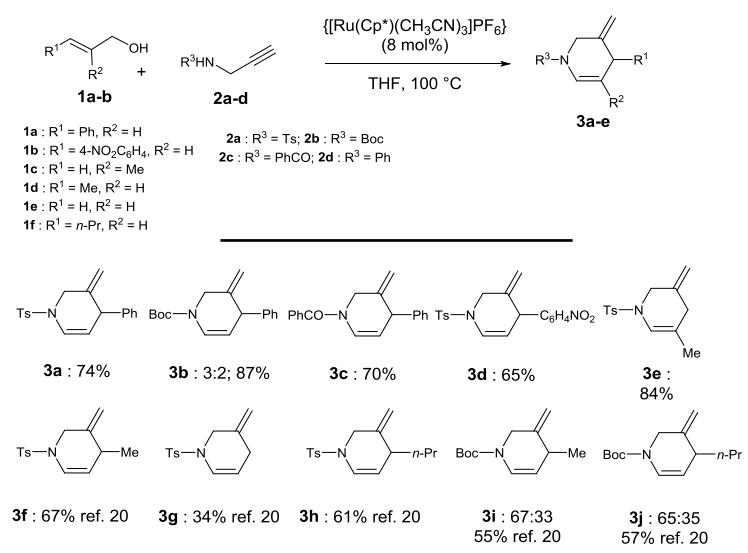

Scheme 1 Access to 3,4- and 3,5-disubstituted enamides 3.

diminished side hemiaminal ether formation in THF yielding from $\mathbf{2 a}$, the 3,5-disubsituted product $\mathbf{3 e}$ in $84 \%$ (Scheme 1). Taken together these results demonstrated that the steric hindrance of the allylic alcohols has a strong impact on the reaction efficiency and linear aliphatic alcohols were found to be more reactive and less

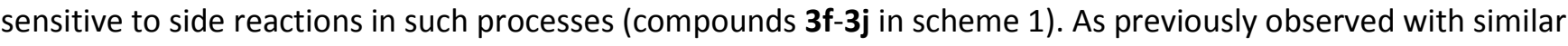
structures, it is noteworthy that performing the reaction in methanol with propargylic amines $\mathbf{2} \mathbf{a}$ and $\mathbf{2} \mathbf{b}$ in the presence of cinnamyl alcohol $\mathbf{1 a}$, cleanly afforded the more stable hemiaminal ethers $\mathbf{4 a}$ and $\mathbf{4 b}$ with a 9:1 diastereoisomeric ratio (Scheme 2). ${ }^{20,21}$
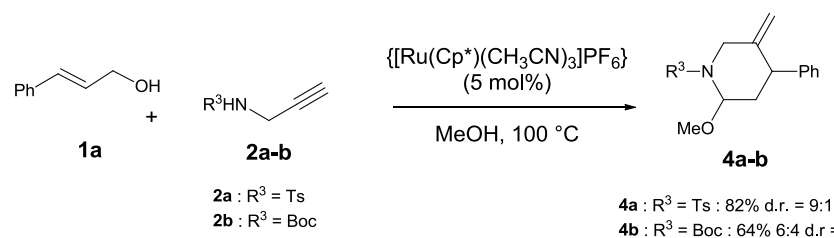

4a: $R^{3}=$ Ts $: 82 \%$ d.r. $=9: 1$

$4 b: R^{3}=$ Boc $: 64 \% 6: 4$ d. $r=9: 1$

Scheme 2 . Preparation of hemiaminal ethers 4. 
Rationalization of these results was next undertaken. Upon non reductive elimination/addition, the propargylic amides $\mathbf{2}$ and allylic alcohols $\mathbf{1}$ react with the cationic [ $\mathrm{Cp} * \mathrm{Ru}]^{+}$fragment to form two key intermediates I and II in equilibrium whereas, the presence of more nucleophilic amine such as propargylic aniline $\mathbf{2} \mathbf{d}$ inhibited the formation of these proposed key intermediates presumably due to the coordination of the nitrogen atom to the ruthenium centre leading to intermediates III (Figure 2). The coordination of the oxygen atom on the cationic ruthenium fragment thus facilitating the introduction of the allylic alcohol in I could also explain the lower activity of the neutral $[\mathrm{Cp} * \mathrm{Ru}(\mathrm{COD}) \mathrm{Cl}]$ in such transformations. ${ }^{20}$ Oxidative cyclization of II gave the cationic ruthenacyclopentene IV. The steric interaction between the $\mathrm{R}^{3}$ group and the $\mathrm{Cp}$ * ligand thus reducing the cyclization rate might account for the lower reactivity of methallyl alcohol 1 c during this process. ${ }^{22}$ Then, intermediate IV undergoes $\beta$-H elimination with the former allylic proton and the ruthenium affording the hydrido ruthenium(IV) $\mathbf{V}$. Reductive elimination from $\mathbf{V}$ gives back the active cationic [Cp*Ru] ${ }^{+}$moiety and generates the intermediate aminoaldehyde $\mathbf{V} \mathbf{I}$, which releases the enamides $\mathbf{3}$ after intramolecular condensation with elimination of water.

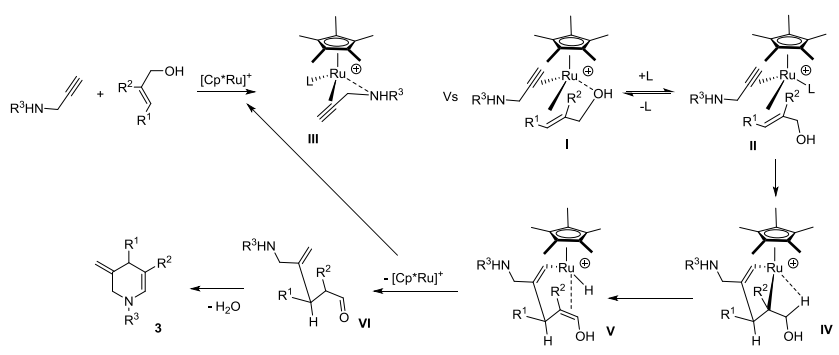

Figure 2 Postulated mechanism accounting on products 3.

Using methanol as solvent, the presence of an excess of cinnamyl alcohol 1a, led to the side formation of (3,3dimethoxypropyl)benzene 5 . Interestingly, we found that the complete formation of this acetal was only possible when $\left\{\left[\mathrm{Ru}\left(\mathrm{Cp}^{*}\right)\left(\mathrm{CH}_{3} \mathrm{CN}\right)_{3}\right] \mathrm{PF}_{6}\right\}$ along with catalytic amount of $2 \mathrm{a}$ were used as catalytic system for this isomerisation-acetalisation sequence (Scheme 3). These last results tend to demonstrate that the generated electrophilic ruthenium species promoted acetal formation and could also play a role during the transformation of intermediate $\mathbf{V I}$ to enamide $\mathbf{3}$.

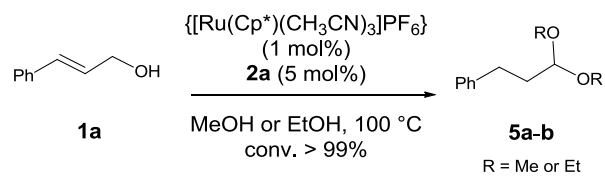

Scheme 3 . [Ru]-catalyzed acetal formation from allylic alcohols.

Considering that products $\mathbf{3}$ and $\mathbf{4}$ feature a methylene group, we next investigated the postfunctionalization of these products in hydroboration-oxidation sequence to access 3-hydroxymethylpiperidine derivatives. The use of Thexylborane with 3a didn't afford the expected product. ${ }^{23}$ To our delight, performing similar reaction with $\mathrm{BH}_{3}$ :DMS made possible the formation of the expected compound along with noticeable amount of side products arising from the side reaction of the endo cyclic insaturation. Finally, replacing $\mathbf{3 a}$ by its corresponding hemiaminal ether $\mathbf{4 a}$ afforded $\mathbf{5 a}$ in a 75:19:6 stereoisomeric mixture and 76\% isolated yield (Scheme 4). 


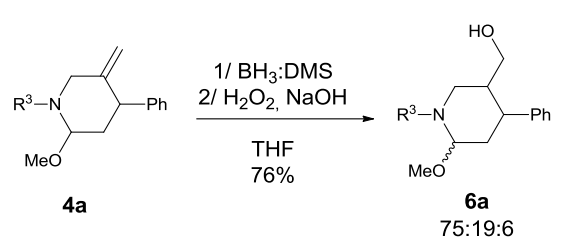

Scheme 4 . Hydroboration-Oxidation of $4 a$.

The beneficial presence of C-Me bonds in alkaloids and heterocycles recently highlighted as the "magic methyl effect" has attracted a lot of interest and can contribute to an increase of their biological activities. ${ }^{24}$ The methylene moiety in products $\mathbf{3}$ could be therefore selectively reduced to a methyl group keeping intact the endo cyclic insaturation for further posfunctionalization. Selective hydrogenation of dienes into alkene in the presence of [Cp*Ru]-based catalyst have been reported by Drießen-Hölscher. ${ }^{25}$ During this study, it was observed that the use of organophosphorous ligand such as tris(hydroxypropyl)phosphane favoured complete hydrogenation of the diene into its corresponding alkane. We investigated the semi-hydrogenation of $3 a$ using $\left\{\left[\mathrm{Ru}\left(\mathrm{Cp}^{*}\right)\left(\mathrm{CH}_{3} \mathrm{CN}_{3}\right] \mathrm{PF}_{6}\right\}\right.$ as precatalyst to further perform the tandem coupling/hydrogenation transformation. ${ }^{26}$ Initial attempt to hydrogenate $3 a$ without additives demonstrated that semi hydrogenation was possible at $120{ }^{\circ} \mathrm{C}$ under 45 bars of $\mathrm{H}_{2}$ but side isomerisation of the exo-insaturation occurred to afford the conjugated diene (Table 2, entry 1).

Table 2 . $\left[\mathrm{Ru}\left(\mathrm{Cp} \mathrm{p}^{*}\right)\right]$-catalyzed semi hydrogenation of enamide $\mathbf{3} \mathbf{a}^{a}$

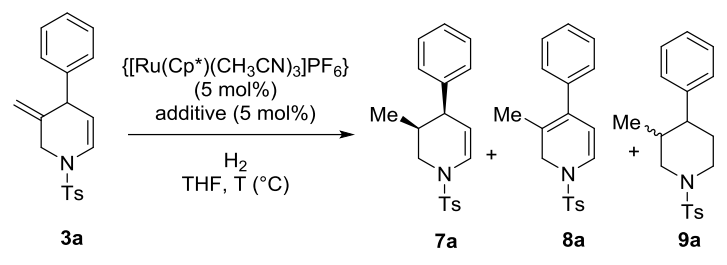

\begin{tabular}{|c|c|c|c|c|c|c|}
\hline Entry & $P($ bar $)$ & $\mathrm{T}\left({ }^{\circ} \mathrm{C}\right)$ & $\begin{array}{l}\text { Additive } \\
\text { (mol\%) }\end{array}$ & $\begin{array}{l}\text { conv. } \\
\text { (yield) }\end{array}$ & $\begin{array}{l}\text { 7/8/9 } \\
\text { Ratio }^{c}\end{array}$ & $\begin{array}{l}7 \text { a } \\
\text { cis/trans } \\
\text { ratio }^{d}\end{array}$ \\
\hline 1 & 45 & 120 & None & 75 & $55 / 35 / 10$ & $70 / 30$ \\
\hline 2 & 45 & 120 & A (5\%) & $99(75)$ & $100 / 0 / 0$ & $70 / 30$ \\
\hline 3 & 45 & 120 & B (5\%) & $99(70)$ & $80 / 0 / 20$ & $80 / 20$ \\
\hline 4 & 35 & 110 & A (5\%) & 99 & $100 / 0 / 0$ & $70 / 30$ \\
\hline 5 & 25 & 120 & A (5\%) & 97 & $95 / 5 / 0$ & $65 / 35$ \\
\hline 6 & 60 & 90 & A (5\%) & 80 & $100 / 0 / 0$ & $75 / 25$ \\
\hline 7 & 65 & 110 & A (5\%) & 99 & $100 / 0 / 0$ & $75 / 25$ \\
\hline 8 & 65 & 110 & B (5\%) & 99 & $90 / 1 / 9$ & $80 / 20$ \\
\hline 9 & 50 & 110 & C (5\%) & 93 & $84 / 2 / 14$ & $80 / 20$ \\
\hline
\end{tabular}

${ }^{a}$ All reactions were carried out in a $20 \mathrm{~mL}$ reactor using THF for $15 \mathrm{~h}$ with 3a/[Ru]/additive in 1/0.05/0.05 molar ratio. ${ }^{b}$ Number in parentheses is isolated yield of 7 a after purification. ${ }^{c}$ ratio $7 / 8 / 9$ were determined by GC. ${ }^{d}$ cis/trans ratio was determined by GC and ${ }^{1} \mathrm{H}$ NMR. 
Recently, Fehr and co-workers at Firmenich showed the beneficial role of Brönsted acid as additive to prevent isomerisation during hydrogenation of dienes for the synthesis of Santalol. ${ }^{27}$ Thus, a set of sulfonic acid derivatives was evaluated for this transformation (Figure 3). Gratifyingly, the use of phosphine-sulfonic acids (5 mol\%) such as $\mathbf{A}$ and $\mathbf{B}$ led to complete conversion and suppress the side isomerisation affording $7 \mathbf{a}$ in up to 7075\% isolated yield and 70:30-80:20 cis:trans ratios, respectively (entries 2 and 3). Best diastereoselectivity was obtained with additive $\mathbf{B}$ (entries 3 and 8 ). However, in these cases noticeable amount of fully reduced products 9a were also observed demonstrating that $\mathbf{A}$ led to the best chemoselectivity. Importantly, lower or higher amount of the acidic additive reduced the catalytic activity. The structure of the major diastereoisomer was unequivocally determined by NMR analyses where the high-field ethylenic protons appeared as a set of two doublet of doublet at 4.77 and $4.68 \mathrm{ppm}$ with a 5.0 and $2.3 \mathrm{~Hz}$ coupling constants with the allylic proton corresponding to the cis and trans isomers, respectively (Figure 4). Further confirmation<smiles>Oc1ccccc1OS</smiles>

A<smiles>O=P(O)(O)c1ccccc1O</smiles>

B<smiles>O=S(=O)(O)c1ccccc1</smiles>

c

Figure 3 . Additives employed during hydrogenation.

was obtained by selective crystallization of the cis isomer 7a (Figure 4). ${ }^{28}$ Interestingly, no degradation occurred during the purification of the enamide $7 \mathbf{a}$ demonstrating its higher stability compared to the homodiene $\mathbf{3 a}$. Performing the reactions at $110-120^{\circ} \mathrm{C}$ in the presence of $\left\{\left[\mathrm{Ru}\left(\mathrm{Cp}^{*}\right)\left(\mathrm{CH}_{3} \mathrm{CN}\right)_{3}\right] \mathrm{PF}_{6}\right\}$ and $\mathbf{A}$ showed that under lower $\mathrm{H}_{2}$ pressure although full conversions were observed, slight decrease of the cis:trans ratio of $7 \mathrm{a}$ were also noticed (entry 4 compared to 7 and entry 2 compared to 5 ). The conversion was affected by reaction temperature and only $80 \%$ was reached at $90{ }^{\circ} \mathrm{C}$ under 60 bar of molecular hydrogen (entry 6 ).
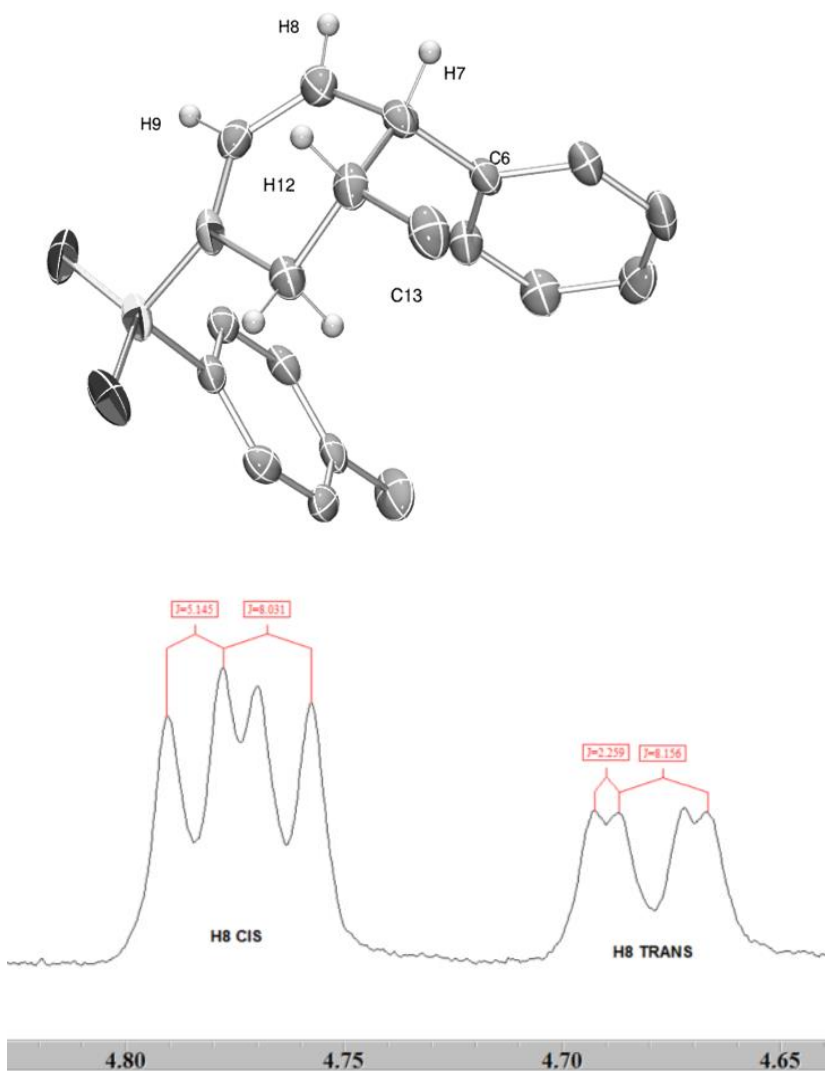
Figure 4 . X-ray structure of the semi reduced cis-cyclic enamide 7a and representative ethylenic proton signals of the two diastereoisomers.

At this stage, we wondered if the diastereoselectivities obtained in the presence of $\mathbf{A}$ and $\mathbf{B}$ arose from the coordination of the phosphine or from simple sterical or acidic outcomes of the additive. Therefore, the use of benzene sulfonic acid C, as additive highlighted similar diastereoselectivity leading to 80:20 cis:trans ratio but with uncompleted conversion, suggesting that with these two phosphine ligands no binding to metal center of the phosphorus atom seems to occur during the hydrogenation in THF as solvent (entry 9).

Although a detailed mechanism for the ruthenium-catalysed alkene hydrogenation ${ }^{29}$ is yet to be established, alkene hydrogenation could occur through consecutive insertion of the coordinated alkene followed by reductive elimination on the cationic hydrido/hydrogen species $\left[\mathrm{Ru}\left(\mathrm{Cp}^{*}\right) \mathrm{H}_{2}\right]^{+} \cdot{ }^{30-31} \mathrm{~A}$ ionic process involving protonation by the acidic $\left[\mathrm{Ru}(\mathrm{Cp} *)\left(n^{2}-\mathrm{H}_{2}\right)\right]^{+}$followed by reduction with side generated neutral $[\mathrm{Ru}(\mathrm{Cp} *) \mathrm{H}]$ cannot totally be excluded. ${ }^{32}$ It should be noted that when the reactions were carried out in the presence of arene ruthenium(II) complexes featuring similar ligands complete reduction of the homodienes were selectively obtained which tend to suggest that the $\mathrm{Cp}$ * ligand remained intact under these reaction conditions. ${ }^{20}$ More important is the influence of the acidic additives on preventing the isomerization processes and toward the reaction efficiency. Recently, Grotjahn and coworkers demonstrated that cationic ruthenium(II) species bearing bifunctional ligand play an important role in isomerization through the possible intervention of allylic ruthenium species where the basic nitrogen of the imidazole facilitates the $\eta^{3}$-allylic formation via reversible deprotonotation. ${ }^{33}$ In contrast, the necessity of acidic additives A-B could prevent the formation of such allylic species via prior protonation/oxidative addition mechanism. On the other hand, Nozaki demonstrated that during hydroformylation of alkenes, $\left[\mathrm{Ru}\left(\mathrm{Cp} \mathrm{P}^{*} \mathrm{H}\right]\right.$ species efficiently catalysed the isomerization through reversible insertion. ${ }^{34}$ Therefore acidic additives might also play a role on the catalytic activity and prevent isomerization by regenerating $\left[\mathrm{Ru}(\mathrm{Cp} *) \mathrm{H}_{2}\right]^{+}$ from neutral $\left[\mathrm{Ru}\left(\mathrm{Cp}^{*}\right) \mathrm{H}\right]$ and dinuclear $(\mu-\mathrm{H})$ monocationic ruthenium(II) species. ${ }^{32-35-37}$

With these results in hand, we investigated the possibility to perform the tandem process with additive $\mathbf{B}$ which afforded better diastereoselectivities. After several attempts, we found that the acidic additive must be added only at the second stage to allow the coupling of propargylic amide 2a with cinnamyl alcohol 1a. Importantly, lower amount of the sulfonic acid $\mathbf{B}$ was necessary demonstrating partial degradation of the catalyst during the initial coupling and required optimization of the reaction conditions to overcome this issue. Thus, initial optimization afforded 7 a in $52 \%$ isolated yield and 75/25 diastereoisomeric ratio (Scheme 5).

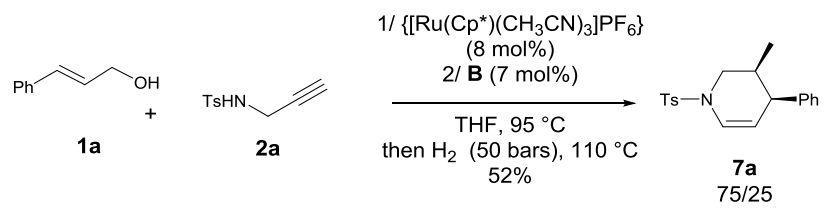

Scheme 5 . Tandem Coupling/Hydrogenation.

\section{Conclusions}

In conclusion, we demonstrated that the selective oxidative coupling between allylic alcohols and propargylic amines can be extended to cinnamyl alcohol derivatives and 2-substituted allylic alcohols. This methodology allows the access to 3,4- and 3,5-disubstituted enamides as valuable scaffolds for the preparation of 3methylpiperidine derivatives through selective $\left[R u\left(C p^{*}\right)\right]$-catalyzed alkene hydrogenation.

\section{Experimental}

\section{General considerations}


All reactions were carried out under an inert atmosphere with standard Schlenk techniques, unless otherwise mentioned. THF was purified by solvent purification system equipped with a series of activated filter columns. Benzene sulfonic acid was purchased from commercial sources and used as received. ligands $\mathbf{A}$ and $\mathbf{B}$ were prepared according literature protocols. ${ }^{38}$ Propargylic amines $\mathbf{2}$ were prepared according to reported procedures.

${ }^{39}$ Compounds $\mathbf{3 f - j}$ were already reported in reference 20 . Proton magnetic resonance $\left({ }^{1} \mathrm{H} N \mathrm{NMR}\right)$ spectra were recorded on Bruker $400 \mathrm{MHz}$ spectrometer and carbon magnetic resonance $\left({ }^{13} \mathrm{C} \mathrm{NMR}\right)$ spectra were performed at $100 \mathrm{MHz}$. Chemical shifts $(\delta)$ are reported in parts per million relative to residual solvent signals $\left(\mathrm{CD}_{2} \mathrm{Cl}_{2} 5.32\right.$ and 53.84; $\mathrm{C}_{6} \mathrm{D}_{6} 7.15$ and $128.02, \mathrm{CD}_{3} \mathrm{OD} 5.84$ and 49.05). Coupling constants are reported in Hertz. ${ }^{1} \mathrm{H}$ NMR assignment abbreviations are the following: singlet $(s)$, doublet $(d)$, triplet $(t)$, quartet $(q)$, pentet $(p)$, broad singlet (bs), doublet of doublets (dd), doublet of triplets (dt), and multiplet $(\mathrm{m})$. All reagents were weighed and handled in air, and refilled with an inert atmosphere of argon at room temperature to prevent oxidation. HRMS were recorded on a Waters Q-Tof 2 with an ESI source.

\section{General Procedure for preparation of the enamides 3-4}

To a dried pressure tube under an inert atmosphere, propargylic amine $\mathbf{2}(0.239 \mathrm{mmol}$, 1eq), allylic alcohol substrate 1 (1.2 eq) were dissolved in THF or methanol $(0.5$ to $1 \mathrm{~mL})$ followed by the addition of $\left\{\left[\mathrm{Ru}\left(\mathrm{Cp}^{*}\right)\left(\mathrm{CH}_{3} \mathrm{CN}\right)_{3}\right] \mathrm{PF}_{6}\right\}(5 \mathrm{~mol} \%(\mathrm{MeOH})$ or $8 \mathrm{~mol} \%(\mathrm{THF}))$. The resulting solution was stirred at $100^{\circ} \mathrm{C}$ for $15 \mathrm{~h}$. Reaction completion was monitored using GC, GC-MS and TLC techniques. After concentration in vacuo, the crude mixture was purified by short column chromatography over dried deactivated silica gel.

\section{3-methylene-4-phenyl-1-tosyl-1,2,3,4-tetrahydropyridine 3a}

Prepared from N-tosyl propargylamine $2 \mathrm{a}(50 \mathrm{mg}, 0.239 \mathrm{mmol})$ and cinnamyl alcohol 1a $(0,288 \mathrm{mmol}, 1.2 \mathrm{eq})$ in THF (0,5 mL). Chromatography on silica gel using PE/Et ${ }_{2} \mathrm{O}(80: 20)$ as eluent afforded compound 3a as yellow oil, $58 \mathrm{mg}(74 \%),{ }^{1} \mathrm{H}$ NMR $\left(400 \mathrm{MHz}, \mathrm{CD}_{2} \mathrm{Cl}_{2}\right) \delta 7.69(\mathrm{~d}, J=8.1 \mathrm{~Hz}, 2 \mathrm{H}), 7.36(\mathrm{~d}, J=8.1 \mathrm{~Hz}, 2 \mathrm{H}), 7.20-7.15(\mathrm{~m}, 3 \mathrm{H}), 6.98$ $6.95(\mathrm{~m}, 2 \mathrm{H}), 6.84(\mathrm{~d}, J=8.0 \mathrm{~Hz}, 1 \mathrm{H}), 5.10(\mathrm{dd}, J=4.4,8.0 \mathrm{~Hz}, 1 \mathrm{H}), 4.90$ (bs, $1 \mathrm{H}), 4.81$ (bs, $1 \mathrm{H}), 3.96(\mathrm{~d}, J=12.9 \mathrm{~Hz}$, $1 \mathrm{H}), 3.93$ (bs, $1 \mathrm{H}), 3.67$ (d, J=12.9 Hz, 1H), $2.45(\mathrm{~s}, 3 \mathrm{H}) ;{ }^{13} \mathrm{C} \mathrm{NMR}\left(100 \mathrm{MHz}, \mathrm{CD}_{2} \mathrm{Cl}_{2}\right) \delta 144.6,142.8,141.4,134.8$, $130.1,128.6,128.2,127.7,127.0,126.5,113.7,110.7,48.3,45.4,21.7$; HRMS calcd for $\mathrm{C}_{19} \mathrm{H}_{19} \mathrm{NO}_{2} \mathrm{NaS}[\mathrm{M}+\mathrm{Na}]^{+}$ 348.10342 found 348.1035 (0 ppm).

\section{Tert-butyl 3-methylene-4-phenyl-3,4-dihydropyridine-1(2H)-carboxylate 3b}

Prepared from N-Boc propargylamine $\mathbf{2 b}$ (50 mg, $0.322 \mathrm{mmol}$ ) and cinnamyl alcohol 1a (1.2 eq, 0,376 mmol) in $\operatorname{THF}(0,7 \mathrm{~mL})$. Chromatography on silica gel using $\mathrm{PE} / \mathrm{Et}_{2} \mathrm{O}(70: 30)$ as eluent afforded compound $\mathbf{3 b}$ as colourless oil as a mixture of isomers in a 3:2 ratio due to the Boc protecting group, (76 mg, 87\%) ${ }^{1} \mathrm{H} \mathrm{NMR}\left(400 \mathrm{MHz}, \mathrm{CD}_{2} \mathrm{Cl}_{2}\right)$ 反 7.32-7.22 (m, 5H), 7.09-6.97 (2bs, $1 \mathrm{H}), 5.06-4.88(\mathrm{~m}, 3 \mathrm{H}), 4.20-4.11(\mathrm{~m}, 1 \mathrm{H}), 4.08(\mathrm{~d}, J=3.6 \mathrm{~Hz}, 1 \mathrm{H}), 3.86(\mathrm{~d}, J=$ $13.6 \mathrm{~Hz}, 1 \mathrm{H}), 1.50$ (bs, 9H) ; ${ }^{13} \mathrm{C}$ NMR $\left(100 \mathrm{MHz}, \mathrm{CD}_{2} \mathrm{Cl}_{2}\right) \delta 152.5$ (II, C=O) 152.1 (I2, C=O), 148.0 , 147.8, 143.6, 143.5, 128.7, 128.3, 126.9, 125.1, $112.6\left(I 1,=\mathrm{CH}_{2}\right), 112.5\left(\mathrm{I} 2,=\mathrm{CH}_{2}\right), 106.4,106.1,81.25,47.4,46.3,45.8,45.7$, 28.4 ; GC-MS m/z (\%): $271\left(\mathrm{M}^{+}, 1 \%\right), 215,200,170,142$.

\section{(3-methylene-4-phenyl-3,4-dihydropyridin-1(2H)-yl)(phenyl)methanone 3c}

Prepared from N-(prop-2-ynyl)benzamide $2 \mathrm{c}(50 \mathrm{mg}, 0.314 \mathrm{mmol})$ and cinnamyl alcohol $1 \mathrm{a}(1.2 \mathrm{eq}, 0,41 \mathrm{mmol})$ in THF (0,6 mL). Chromatography on silica gel using $\mathrm{PE} / \mathrm{Et}_{2} \mathrm{O}(70: 30)$ as eluent afforded compound $3 \mathrm{c}$ as colourless oil, $61 \mathrm{mg}(70 \%){ }^{1} \mathrm{H}$ NMR $\left(400 \mathrm{MHz}, \mathrm{CD}_{2} \mathrm{Cl}_{2}\right)$ 8 7.52-7.43 (m, 5H), 7.35-7.23 (m, 5H), 6.73-6.70 (m, 1H), 5.16-5.14 $(\mathrm{m}, 1 \mathrm{H}), 5.00-4.93(\mathrm{~m}, 2 \mathrm{H}), 4.48(\mathrm{~d}, J=13.4 \mathrm{~Hz}, 1 \mathrm{H}), 4.18-4.16(\mathrm{~m}, 1 \mathrm{H}), 4.11(\mathrm{~d}, J=13.4 \mathrm{~Hz}, 1 \mathrm{H}) ;{ }^{13} \mathrm{C} \mathrm{NMR}(100 \mathrm{MHz}$, $\left.\mathrm{CD}_{3} \mathrm{OD}\right)$ $\delta$ 171.0, 144.0, 143.7, 135.9, 131.9, 129.8, 129.6, 129.2, 129.1, 128.8, 127.9, 114.0, 111.3, 47.3, 47.0 ; HRMS calcd. for $\mathrm{C}_{19} \mathrm{H}_{17} \mathrm{NONa}[\mathrm{M}+\mathrm{Na}]^{+} 298.12078$ found 298.1207 (0 ppm). 


\section{3-methylene-4-(4-nitrophenyl)-1-tosyl-1,2,3,4-tetrahydropyridine 3d}

Prepared from N-tosyl propargylamine $2 \mathrm{a}(50 \mathrm{mg}, 0.239 \mathrm{mmol})$ and 4-nitrocinnamyl alcohol 1a (1.2 eq, 0,286 $\mathrm{mmol}$ ) in THF (0,5 mL). Chromatography on silica gel using PE/Et $\mathrm{O}_{2} \mathrm{O}(50: 50)$ as eluent afforded compound $\mathbf{3 d}$ as colourless oil, $57 \mathrm{mg}(65 \%){ }^{1} \mathrm{H}$ NMR $\left(400 \mathrm{MHz}, \mathrm{C}_{6} \mathrm{D}_{6}\right) \delta 7.65(\mathrm{~d}, J=8.6 \mathrm{~Hz}, 2 \mathrm{H}), 7.58(\mathrm{~d}, J=8.2 \mathrm{~Hz}, 2 \mathrm{H}), 6.90,(\mathrm{dd}, J=$ 1.6, $8.1 \mathrm{~Hz}, 1 \mathrm{H}$ ), $6.72(\mathrm{~d}, J=8.2 \mathrm{~Hz}, 2 \mathrm{H}), 6.42(\mathrm{~d}, J=8.6 \mathrm{~Hz}, 2 \mathrm{H}), 4.49$ (bs, $1 \mathrm{H}), 4.47$ (dd, J=4.4, $8.1 \mathrm{~Hz}, 1 \mathrm{H}$ ), 4.30 (bs, $1 \mathrm{H}), 3.80(\mathrm{~d}, J=13.0 \mathrm{~Hz}, 1 \mathrm{H}), 3.50(\mathrm{~d}, J=13.0 \mathrm{~Hz}, 1 \mathrm{H}), 3.30(\mathrm{~d}, J=3.5 \mathrm{~Hz}, 1 \mathrm{H}), 1.88(\mathrm{~s}, 3 \mathrm{H}) ;{ }^{13} \mathrm{C} \mathrm{NMR}\left(100 \mathrm{MHz}, \mathrm{C}_{6} \mathrm{D}_{6}\right)$ $\delta$ 149.3, 147.1, 143.8, 140.0, 135.4, 129.7, 128.6, 128.1, 127.6, 123.4, 114.0, 107.9, 47.9, 44.7, 21.0 ; HRMS calcd. for $\mathrm{C}_{19} \mathrm{H}_{18} \mathrm{~N}_{2} \mathrm{NaO}_{4} \mathrm{~S}[\mathrm{M}+\mathrm{Na}]^{+}$393.0885, found 393.0884 (0 ppm).

\section{5-methyl-3-methylene-1-tosyl-1,2,3,4-tetrahydropyridine 3e}

Prepared from N-tosyl propargylamine $2 \mathrm{a}(50 \mathrm{mg}, 0.239 \mathrm{mmol}$ ) and 2-methylprop-2-en-1-ol 1c (5 eq, $1.19 \mathrm{mmol})$ in THF (1 mL). Chromatography on silica gel using DCM/PE/Et ${ }_{2} \mathrm{O}(80: 10: 10)$ as eluent afforded compound $3 e$ as colourless oil (53 mg, 84\%); $\left.{ }^{1} \mathrm{H} \mathrm{NMR} \mathrm{(400} \mathrm{MHz,} \mathrm{CD} 3 \mathrm{OD}\right) \delta 7.64$ (d, J=8.1 Hz, 2H), 7.35 (d, J=8.1 Hz, 2H), 6.40 (bs, $1 \mathrm{H}), 4.82(\mathrm{~s}, 1 \mathrm{H}), 4.81(\mathrm{~s}, 1 \mathrm{H}), 3.83(\mathrm{~s}, 2 \mathrm{H}), 2.56(\mathrm{~s}, 2 \mathrm{H}), 2.41(\mathrm{~s}, 3 \mathrm{H}), 1.67(\mathrm{~s}, 3 \mathrm{H}) ;{ }^{13} \mathrm{C} \mathrm{NMR}\left(100 \mathrm{MHz}, \mathrm{CD}_{3} \mathrm{OD}\right) \delta$ $145.2,138.5,136.2,130.6,128.5,120.8,119.8,112.5,50.5,35.6,21.4,20.3 ; \mathrm{HRMS}$ calcd for $\mathrm{C}_{14} \mathrm{H}_{17} \mathrm{NO}_{2} \mathrm{NaS}$ $[\mathrm{M}+\mathrm{Na}]^{+} 286.0877$ found $286.0876(1 \mathrm{ppm})$.

\section{2-methoxy-5-methylene-4-phenyl-1-tosylpiperidine 4a}

Prepared from N-tosyl propargylamine $2 \mathrm{a}(50 \mathrm{mg}, 0.239 \mathrm{mmol})$ and cinnamyl alcohol 1a $(1.2 \mathrm{eq}, 0,288 \mathrm{mmol})$ in $\mathrm{MeOH}(0,5 \mathrm{~mL})$. Chromatography on silica gel using PE/ $\mathrm{Et}_{2} \mathrm{O}(70: 30)$ as eluent afforded compound 4 a as yellow oil in a 93/7 diastereoisomeric mixture (70 mg, 82\%), ${ }^{1} \mathrm{H}$ NMR $\left(400 \mathrm{MHz}, \mathrm{C}_{6} \mathrm{D}_{6}\right) \delta 7.74(\mathrm{~d}, J=8.2 \mathrm{~Hz}, 2 \mathrm{H}), 7.06-6.98(\mathrm{~m}$, $3 \mathrm{H}), 6.79-6.77(\mathrm{~m}, 4 \mathrm{H}), 5.26(\mathrm{t}, J=0.5 \mathrm{~Hz}, 1 \mathrm{H}), 4.59(\mathrm{bs}, 1 \mathrm{H}), 4.27(\mathrm{~d}, J=14.3 \mathrm{~Hz}, 1 \mathrm{H}), 4.10(\mathrm{bs}, 1 \mathrm{H}), 3.84(\mathrm{~d}, J=14.3$ $\mathrm{Hz}, 1 \mathrm{H}), 3.74-3.70(\mathrm{~m}, 1 \mathrm{H}), 3.23(\mathrm{~s}, 3 \mathrm{H}), 1.89(\mathrm{~s}, 3 \mathrm{H}), 1.84$ (ddd, J=2.0, 4.1, $13.2 \mathrm{~Hz}, 1 \mathrm{H}), 1.59$ (dt, J= 3.2, $13.1 \mathrm{~Hz}$, $1 \mathrm{H}) ;{ }^{13} \mathrm{C}$ NMR $\left(100 \mathrm{MHz}, \mathrm{C}_{6} \mathrm{D}_{6}\right) \delta 134.8,142.8,141.3,138.9,129.5,128.8,128.6,127.8,127.0,111.8,84.8,55.0$, 47.6, 42.0, 36.7, 21.0; HRMS calcd for $\mathrm{C}_{20} \mathrm{H}_{23} \mathrm{NO}_{3} \mathrm{NaS}[\mathrm{M}+\mathrm{Na}]^{+} 380.12964$ found 380.1289 (1 ppm).

\section{Tert-butyl 2-methoxy-5-methylene-4-phenylpiperidine-1-carboxylate 4b}

Prepared from N-Boc propargylamine $\mathbf{2 b}(50 \mathrm{mg}, 0.322 \mathrm{mmol})$ and cinnamyl alcohol $\mathbf{1 a}(1.2 \mathrm{eq}, 0,387 \mathrm{mmol})$ in $\mathrm{MeOH}(0,6 \mathrm{~mL})$. Chromatography on silica gel using PE/Et ${ }_{2} \mathrm{O}(70: 30)$ as eluent afforded compound $\mathbf{4} \mathbf{b}$ as colourless oil, $62 \mathrm{mg}$ (64\%), as two isomers due to the Boc protecting group (63/37 ratio) in a 90/10 diastereoisomeric ratio. ${ }^{1} \mathrm{H} \mathrm{NMR}\left(400 \mathrm{MHz}, \mathrm{CD}_{2} \mathrm{Cl}_{2}\right) \delta 7.32(\mathrm{t}, J=7.2 \mathrm{~Hz}, 2 \mathrm{H}), 7.24$ (td, J= 7.2, $\left.1.1 \mathrm{~Hz}, 1 \mathrm{H}\right), 7.19$ (brd, J= 7.2 Hz, 2H), 5.55 (bs, $0.4 \mathrm{H}$ ), 5.44 (bs, 0.6H), 4.93-4.87 (m, $1 \mathrm{H}), 4.47(\mathrm{~d}, J=14.0 \mathrm{~Hz}, 0.6 \mathrm{H}), 4.35-4.32(\mathrm{~m}, 0.4 \mathrm{H}), 4.13$ (bs, $1 \mathrm{H}), 3.80$ (dd, J= $14.0,4.0 \mathrm{~Hz}, 1 \mathrm{H}), 3.74(\mathrm{~d}, \mathrm{~J}=14.0 \mathrm{~Hz}, 0.4 \mathrm{H}), 3.64(\mathrm{~d}, \mathrm{~J}=14.0 \mathrm{~Hz}, 0.6 \mathrm{H}), 3.30(\mathrm{~s}, 2.6 \mathrm{H}), 3.28(\mathrm{~s}, 0.4 \mathrm{H}), 1.48(\mathrm{~s}, 9 \mathrm{H}) ;{ }^{13} \mathrm{C}$ NMR $\left(100 \mathrm{MHz}, \mathrm{CD}_{2} \mathrm{Cl}_{2}\right) \delta 155.0,154.6,147.2,146.9,142.9,141.9,129.0,128.8,128.7,128.6,127.0,126.8,110.8$, $110.6,82.9,81.9,80.5,80.2,54.9,54.8,46.8,45.3,43.0,42.5,37.8,37.5,28.5,28.4$; HRMS calcd for $\mathrm{C}_{18} \mathrm{H}_{25} \mathrm{NO}_{3} \mathrm{NaS}([\mathrm{M}+\mathrm{Na}])^{+} 326.17321$ found 326.1728 (0 ppm).

\section{General Procedure for preparation of the acetals 5}

To a dried pressure tube under an inert atmosphere, propargylic amine $2 \mathrm{a}(5 \mathrm{~mol} \%)$ and $\left\{\left[\mathrm{Ru}\left(\mathrm{Cp}^{*}\right)\left(\mathrm{CH}_{3} \mathrm{CN}_{3}\right] \mathrm{PF}_{6}\right\}(1\right.$ mol\%) were dissolved in methanol or ethanol $(1 \mathrm{~mL}$ ) followed by the addition of cinnamyl alcohol $1 \mathrm{a}$ (1.0 eq). The resulting solution was stirred at $100^{\circ} \mathrm{C}$ overnight. After concentration in vacuo, the crude mixture was purified by short column chromatography to afford the acetal 5 as product.

\section{(3,3-dimethoxypropyl)benzene $5 a^{40}$}


Prepared from cinnamyl alcohol 1a $\left(50 \mathrm{mg}, 0.239 \mathrm{mmol}\right.$ ) and $\mathrm{MeOH}(1 \mathrm{~mL})$. Filtration on silica gel using PE/Et ${ }_{2} \mathrm{O}$ $(80: 20)$ as eluent afforded compound $5 \mathrm{a}$ in $90 \%$ yield. ${ }^{1} \mathrm{H} \mathrm{NMR}\left(400 \mathrm{MHz}, \mathrm{C}_{6} \mathrm{D}_{6}\right) \delta$ 7.12-6.98 (m, 5H), $4.18(\mathrm{t}, J=5.6$ $\mathrm{Hz}, 1 \mathrm{H}), 3.15(\mathrm{~s}, 6 \mathrm{H}), 2.48(\mathrm{t}, \mathrm{J}=8.15 \mathrm{~Hz}, 2 \mathrm{H}), 1.74-1.69(\mathrm{~m}, 2 \mathrm{H})$.

\section{(6-methoxy-4-phenyl-1-tosylpiperidin-3-yl)methanol 6a}

$\mathrm{BH}_{3}$ :DMS ( $\mathrm{C}=1 \mathrm{M}, 0.3 \mathrm{~mL}$ ) was slowly added to a solution containing 2-methoxy-5-methylene-4-phenyl-1tosylpiperidine $4 \mathrm{a}(30 \mathrm{mg}, 0.08 \mathrm{mmol})$ in THF $(0.5 \mathrm{~mL})$ at $0^{\circ} \mathrm{C}$ and the resulting mixture was stirred for 2 hours. $\mathrm{H}_{2} \mathrm{O}_{2}(30 \%, 0.08 \mathrm{~mL})$ and $\mathrm{NaOH}(3 \mathrm{~N}, 0.08 \mathrm{~mL})$ were sequentially added and the stirring was maintained for $3 \mathrm{~h}$ at room temperature. Extraction with $\mathrm{H}_{2} \mathrm{O}$ and $\mathrm{CH}_{2} \mathrm{Cl}_{2} \times 3$ followed by drying over sodium sulfate and concentration afforded a crude oil which was further purified by chromatography on silica gel using $\mathrm{PE} / \mathrm{Et}_{2} \mathrm{O}(80: 20)$ as eluent to afford compound 6 a as yellow oil $(24 \mathrm{mg}, 76 \%)$ in a 75:19:6 stereoisomeric ratio (only the major compound is described), ${ }^{1} \mathrm{H}$ NMR $\left(400 \mathrm{MHz}, \mathrm{C}_{6} \mathrm{D}_{6}\right) \delta 7.74(\mathrm{~d}, J=8.1 \mathrm{~Hz}, 2 \mathrm{H}), 7.10-7.01(\mathrm{~m}, 3 \mathrm{H}), 6.82-6.77(\mathrm{~m}, 4 \mathrm{H}), 5.34(\mathrm{t}, J=0.4$ $\mathrm{Hz}, 1 \mathrm{H}), 4.04(\mathrm{~d}, J=13.0 \mathrm{~Hz}, 1 \mathrm{H}), 3.44(\mathrm{t}, J=10.5 \mathrm{~Hz}, 1 \mathrm{H}), 3.33(\mathrm{td}, J=4.0,13.0 \mathrm{~Hz}, 1 \mathrm{H}), 3.28-3.20(\mathrm{~m}, 1 \mathrm{H}), 3.14-3.06$ $(\mathrm{m}, 2 \mathrm{H}), 2.95(\mathrm{~s}, 3 \mathrm{H}), 1.92-1.82(\mathrm{~m}, 1 \mathrm{H}), 1.87(\mathrm{~s}, 3 \mathrm{H}), 1.79-1.68(\mathrm{~m}, 2 \mathrm{H}) ;{ }^{13} \mathrm{C} \mathrm{NMR}\left(100 \mathrm{MHz}, \mathrm{C}_{6} \mathrm{D}_{6}\right), \delta 141.5,141.2$, $137.4,128.1,127.2,126.2,126.1,125.2,83.0,56.0,53.9,40.6,39.8,35.1,28.6,19.7$; HRMS calcd for $\mathrm{C}_{20} \mathrm{H}_{25} \mathrm{NO}_{4} \mathrm{NaS}[\mathrm{M}+\mathrm{Na}]^{+} 398.14020$ found 398.1403 (0 ppm).

\section{General Procedure for the semi-hydrogenation of $3 a$.}

In a $20 \mathrm{~mL}$ reactor, containing 3-methylene-4-phenyl-1-tosyl-1,2,3,4-tetrahydropyridine $3 \mathrm{a}$ (30 $\mathrm{mg}, 0.09 \mathrm{mmol}$ ), THF $\left(2 \mathrm{~mL}\right.$ ) was added followed by the addition of $\left.\left\{\mathrm{Ru}\left(\mathrm{Cp}^{*}\right)\left(\mathrm{CH}_{3} \mathrm{CN}\right)_{3}\right] \mathrm{PF}_{6}\right\}$ and the additive $(5 \mathrm{~mol} \%)$. The autoclave was sealed, and was fast evacuated and filled with argon three times then ended with vacuum. The molecular hydrogen was introduced into the reactor at the indicated pressure. Then, the mixture was stirred at the mentioned temperature. After 15 hours the autoclave was cooled down to the room temperature and the hydrogen was then carefully released, the conversion was determined by GC, GC-MS and crude ${ }^{1} \mathrm{H}$ NMR. Chromatography on silica gel using PE/Et ${ }_{2} \mathrm{O}(80: 20)$ as eluent afforded compound 7 a as yellow oil, as yellow oil, $\delta$ $22.5 \mathrm{mg}(75 \%)$, (only the cis compound is described) ${ }^{1} \mathrm{H} N M R\left(400 \mathrm{MHz}, \mathrm{C}_{6} \mathrm{D}_{6}\right) \delta 7.68(\mathrm{~d}, \mathrm{~J}=7.8 \mathrm{~Hz}, 2 \mathrm{H}), 7.06-6.92$ $(\mathrm{m}, 4 \mathrm{H}), 6.79-6.75(\mathrm{~m}, 3 \mathrm{H}), 6.60(\mathrm{~d}, J=6.9 \mathrm{~Hz}, 1 \mathrm{H}), 4.77(\mathrm{dd}, J=5.0,8.2 \mathrm{~Hz}, 1 \mathrm{H}), 3.39(\mathrm{dd}, J=1.7,10.9 \mathrm{~Hz}, 1 \mathrm{H}), 2.86$ $(\mathrm{t}, J=5.0 \mathrm{~Hz}, 1 \mathrm{H}), 2.80(\mathrm{t}, J=10.9 \mathrm{~Hz}, 1 \mathrm{H}), 1.88(\mathrm{~s}, 3 \mathrm{H}), 1.76-1.68(\mathrm{~m}, 1 \mathrm{H}), 0.29(\mathrm{~d}, J=6.7 \mathrm{~Hz}, 3 \mathrm{H}) ; 13 \mathrm{C} N \mathrm{NR}(100$ $\left.\mathrm{MHz}, \mathrm{CD}_{2} \mathrm{Cl}_{2}\right) \delta 144.5,140.8,134.9,130.2,129.7,128.0,127.6,126.9,125.6,110.0,46.7,42.6,30.1,20.0,14.3$; HRMS calcd for $\mathrm{C}_{19} \mathrm{H}_{21} \mathrm{NO}_{2} \mathrm{SNaS}([\mathrm{M}+\mathrm{Na}])^{+} 350.11907$ found 350.119 (0 ppm).

\section{Acknowledgements}

The authors thank Dr. Vincent Dorcet for X-Ray analysis and Dr. Sourisak Sinbandhit for 2D NMR-analyses. F. J. thanks the European Union (FP-7 integrated project Synflow, NMP-2009-3.2-1 n²46461; http://synflow.eu) for fellowship.

\section{Notes and References}

${ }^{a}$ UMR6226 CNRS, Insitut des Sciences chimiques de Rennes, Université de Rennes1, OMC : Organometallics : Material and Catalysis Campus de Beaulieu, 35042 Rennes Cedex (France) Fax: (+33) 223236939. E-mail: mathieu.achard@univ-rennes1.fr

${ }^{b}$ University of Constantine 1, Department of Chemistry, Laboratory of Therapeutic Substances Obtention (LOST), Chaabet Ersas campus, 25000 Constantine (Algeria) Fax: (+213)31811100. E-mail: zkabouche@yahoo.com 
1 General references: (a) S. A. Lawrence, Amines : Synthesis, Properties and Applications, Cambridge University Press 2004; (b) T. C. Nugent, Chiral Amine Synthesis: Methods, Development and Applications, WileyVCH Verlag 2010.

2 (a) T. E. Müller, K. C. Hultzsch, M. Yus, F. Foubelo and M. Tada, Chem. Rev., 2008, 108, 3795; (b) R. Yamaguchi, K. -I. Fujita and M. Zhu, Heterocycles, 2010, 81, 1093; (c) K. D. Hesp and M. Stradiotto, ChemCatChem, 2010, 2, 1192; (d) J. -H. Xie, S. -F. Zhu, Q. -L. Zhou, Chem. Rev., 2011, 111, 1713; (e) S. Bähn, S. Imm, L. Neubert, M. Zhang, H. Neumann and M. Beller, ChemCatChem, 2011, 3, 1853. (f) D. Seidel, Org. Chem. Front., 2014, 1, 426; (g) C. -X. Zhuo, C. Zheng and S. -L. You, Acc. Chem. Res. 2014, 47, 2558.

3 Review : S. Källstrom and R. Leino, Bioorg. Med. Chem., 2008, 16, 601.

4 Selected references : (a) M. Amat, O. Lozano, C. Escolano, E. Molins and J. Bosch, J. Org. Chem., 2007, 72, 4431; (b) L. Czibula, A. Nemes, F. Sebök, C. Szántay and M. Mák, Eur. J. Org. Chem., 2004, 3336.

5 T. Harrison, A. J. Owens, B. J. Williams, C. J. Swain, R. Baker, P. H. Huson, S. Sadowski and M. A. Cascieri, Bioorg. Med. Chem. Lett., 1995, 5, 209.

6 Y. Li, Z. Xue, W. Ye, J. Liu, J. Yao and C. Wang, ACS Comb. Sci., 2014, 16, 113. And references cited therein.

$7 \quad$ For an overview of redox neutral processes see: (a) C. Zhang, C. Kanta De, R. Mal and D. Seidel, J. Am. Chem. Soc., 2008, 130, 416; (b) W. Shen, Y. Kang, R. G. Wilde and D. Seidel, Angew. Chem. Int. Ed., 2014, 53, 5179.

8 (a) F. Troxler, Helv. Chim. Acta, 1973, 56, 374; (b) S. Duttwyler, S. Chen, C. Lu, B. Q. Mercado, R. G. Bergman and J. A. Ellman, Angew. Chem. Int. Ed., 2014, 53, 3877.

9 Y. Tsuji, K. -T. Huh, Y. Ohsugi and Y. Watanabe, J. Org. Chem., 1985, 50, 1365

10 (a) I. Jovel, S. Prateeptongkum, R. Jackstell, N. Vogl, C. Weckbecker and M. Beller, Chem. Commun., 2010, 46, 1956; (b) K. Yuan, F. Jiang, Z. Sahli, M. Achard, T. Roisnel and C. Bruneau, Angew. Chem. Int. Ed., 2012, 51, 8876; (c) Z. Sahli, B. Sundararaju, M. Achard and C. Bruneau, Green Chem., 2013, 15, 775.

11 C. -H. Li, Acc. Chem. Res., 2009, 42, 335.

12 N. Gigant, L. Chausset-Boissarie and I. Gillaizeau, Chem. Eur. J., 2014, 20, 7548.

13 (a) E. A. Mitchell, A. Peschiulli, N. Lefevre, L. Meerpoel and B. U. W. Maes, Chem. Eur. J., 2012, 18, 10092; (b) A. Millet, P. Larini, E. Clot and O. Baudoin, Chem. Sci., 2013, 4, 2241.

14 (a) C. F. Caley and S. Weber, Ann. Pharmacother., 1993, 27, 1212; (b) J. E. Kristiansen and J. Bondo Hansen, Int. J. Antimicrob. Ag., 2000, 14, 209; (c) A. J. Wagstaff, S. M. Cheer, A. J. Matheson, D. Ormrod and K. L. Goa, Drugs, 2002, 62, 655.

15 P. N. Reeby, C. Yiptong, J. Samsoon, F. Schulsinger and J. Fabricius, Pharmacopsychiatry, 1982, $15,164$.

16 R. B. Carter and L. A. Dykstra, J. Pharmacol. Exp. Ther., 1985, 234, 299.

17 X. Gu, S. Izenwasser, D. Wade, A. Housman, G. Gulasey, J. B. Rhoden, C. D. Savoie, D. L. Mobley, S. A. Lomenzo and M. L. Trudell, Bioorg. Med. Chem., 2010, 18, 8356.

18 (a) P. A. J. Janssen, C. van de Westeringh, A. H. M. Jageneau, P. J. A. Demoen, B. K. F. Hermans, G. H. P. van Daele, K. H. L. Schellekens,C. A. M. van der Eycken and C. J. E. Niemegeers, J. Med. Pharm. Chem., 1959, 1, 281; (b) S. W. Tam and L. Cook, Proc. Natl. Acad. Sci. USA, 1984, 81, 5618. 
(a) N. Gigant, L. Chausset-Boissarie and I. Gillaizeau, Org. Lett., 2013, 15, 816; (b) C. F. Despiau, A. P. Dominey, D. C. Harrowven and B. Linclau, Eur. J. Org. Chem., 2014, 4335.

20 S. Murugesan, F. Jiang, M. Achard, C. Bruneau and S. Dérien, Chem. Commun., 2012, 48, 6589.

21 R. C. Clark, S. S. Pfeiffer and D. L. Boger, J. Am. Chem. Soc. 2006, 128, 2587.

22 (a) Trost: B. M. Trost, J. -P. Surivet and F. D. Toste, J. Am. Chem. Soc. 2004, 126, 15592. (b) S. Dérien, L. Ropartz, J. Le Paih and P. H. Dixneuf, J. Org. Chem., 1999, 64, 3524.

23 (a) G. Zweifel and H. C. Brown, J. Am. Chem. Soc., 1963, 85, 2066; (b) F. Karaki, Y. Kabasawa, T. Yanagimoto, N. Umeda, Firman, Y. Urano, T. Nagano, Y. Otani and T. Ohwada, Chem. Eur. J., 2012, 18, 1127.

24 H. Schönherr and T. Cernak, Angew. Chem. Int. Ed., 2013, 52, 12256.

25 (a) B. Drießen-Hölscher and J. Heinen, J. Organomet. Chem., 1998, 570, 141; (b) S. Steines, B. DrießenHölscher and U. Englert, Chem. Commun. 2000, 217.

26 Review on tandem transformations: D. E. Fogg and E. N. dos Santos, Coord. Chem. Rev., 2004, $248,2365$.

27 (a) C. Fehr, I. Magpantay, M. Vuagnoux and P. Dupau, Chem. Eur. J., 2011, 17, 1257. (b) P. Dupau, Top. Organomet. Chem. 2012, 42, 47.

28 CCDC 1014288 contains the supplementary crystallographic data for this paper.

29 For ruthenium-catalysed alkene hydrogenation see selected references: (a) A. J. Lindsay, G. McDermott and G. Wilkinson, Polyhedron, 1988, 7, 1239; (b) C. S. Yi, D. W. Lee and Z. He, Organometallics, 2000, 19, 2909; (c) U. L. Dharmasena, H. M. Foucault, E. N. dos Santos, D. E. Fogg and S. P. Nolan, Organometallics, 2005, 24, 1056; (d) B. Bagh and D. W. Stephan, Dalton Trans., 2014, 43, 15638.

30 M. S. Chinn and M. Heinekey, J. Am. Chem. Soc. 1990, 112, 5166.

31 For the effect of water media during hydrogenation of benzylidene acetone see: (a) D. N. Akbayeva, L. Gonsalvi, W. Oberhauser, M. Peruzzini, F. Vizza, P. Brüggeller, A. Romerosa, G. Sava and A. Bergamo, Chem. Commun. 2003, 264; (b) B. J. Frost and C. A. Mebi, Organometallics 2004, 23, 5317.

32 (a) R. M. Bullock, Chem. Eur. J. 2004, 10, 2366. (b) P. Ghosh, P. J. Fagan, W. J. Marshall, E. Hauptman and R. M. Bullock, Inorg. Chem. 2009, 48, 6490.

33 (a) D. B. Grotjahn, C. R. Larsen, J. L. Gustafson, R. Nair and A. Sharma, J. Am. Chem. Soc. 2007, 129, 9592; (b) C. R. Larsen and D. B. Grotjahn, J. Am. Chem. Soc. 2012, 134, 10357.

34 K. Takahashi, M. Yamashita, Y. Tanaka and K. Nozaki, Angew. Chem. Int. Ed. 2012, 51, 4383.

35 For the formation of ion pairs from sulfonic acids and [ $\left.\mathrm{Cp}^{\prime} \mathrm{RuH}\left(\mathrm{PPh}_{3}\right)_{2}\right]$ see : T. Wilczewski, J. Organomet. Chem. 1989, 361, 219.

36 For the influence of protic media/additives with $\left[\mathrm{Cp}^{\prime} \mathrm{RuH}\right]$ and $[\mathrm{RuH}]$ species see selected references: $(a)$ M. Kranenburg, P. C. J. Kamer, P. W. N. M. van Leeuwen and B. Chaudret, J. Chem. Soc., Chem. Commun. 1997, 373. (b) J. A. Ayllon, S. F. Sayers, S. Sabo-Etienne, B. Donnadieu B. Chaudret and E. Clot, Organometallics 1999, 18, 3981; (c) S. Gründermann, S. Ulrich, H. -H. Limbach, N. S. Golubev, G. S. Denisov, L. M. Epstein, S. Sabo-Etienne and B. Chaudret, Inorg. Chem. 1999, 38, 2550; (d) N. V. Belkova, M. Besora, L. M. Epstein, A. Lledos, F. Maseras and E. S. Shubina, J. Am. Chem. Soc. 2003, 125, 7715; (e) F. A. Jalón, B. R. Manzano, A. Caballero, M. C. Carrión, L. Santos, G. Espino and M. Moreno, J. Am. Chem. Soc. 2005, 127, 15364; (f) V. A. Levina, O. A. Filippov, E. I. Gutsul, 
N. V. Belkova, L. M. Epstein, A. Lledos and E. S. Shubina, J. Am. Chem. Soc. 2010, 132, 11234; (g) G. A. Silantyev, O. A. Filippov, P. M. Tolstoy, N. V. Belkova and L.M. Epstein, Inorg. Chem. 2013, 52, 1787.

37 (a) M. V. Ovchinnikov, E. LeBlanc, I. A. Guzei and R. J. Angelici, J. Am. Chem. Soc. 2001, 123, 11494. (b) H. Suzuki, T. Kakigano, K. -I. Tada, M. Igarashi, K. Matsubara, A. Inagaki, M. Oshima and T. Takao, Bull. Chem. Soc. Jpn. 2005, 78, 67.

38 (a) W. Weng, Z. Shen and R. F. Jordan, J. Am. Chem. Soc., 2007, 129, 15450. (b) B. Sundararaju, Z. Tang, M. Achard, G. V. M. Sharma and C. Bruneau, Adv. Synth. Catal. 2010, 352, 3141.

39 (a) M. B. Kay, C. Hongfeng, S. Peter and Y. Lingfeng, J. Am. Chem. Soc., 2002, 124, 15186; (b) T. D. Travis, Z. Xiaodong and R. C. John, J. Med. Chem., 2005, 48, 224; (c) M. Botta, F. Corelli, E. Petricci and C. Seri, Heterocycles, 2002, 56, 369.

40 Suzuki, T.; Oriyama, T. Synth. Commun. 1999, 29, 1263. 